\title{
A CRITICAL ENQUIRY INTO TEFL: FROM ROOT ORIGINS TO THE NON-NATIVE CONTEXTS OF THE EXPANDING CIRCLE
}

\author{
HAYAT AL-KHATIB ${ }^{1}$ \\ Arab Open University, \\ Lebanon
}

Rad se bavi predavanjem engleskog u zemljama tzv. kruga koji se širi odnosno najšireg kruga (koristeći model koji je predložio Kachru). Upoređuju se anglistički master studijski programi univerziteta u Libanu i u Velikoj Britaniji, pri čemu je sprovedena anketa u Libanu među 21 studentom engleskog jezika i 32 predavača. Autor smatra da se tradicionalni TEFL modeli moraju menjati i prilagoditi sociolingvističkim potrebama učenika u zemljama najšireg kruga, odnosno da ne valja koristiti jedan te isti model, baziran na zemljama unutrašnjeg kruga, u svim zemljama u kojima se engleski uči kao strani jezik.

Ključne reči: globalni engleski, krug koji se širi, unutrašnji krug, sociolingvistička situacija, TEFL.

\section{INTRODUCTION}

The spread of English, through globalization, as the main international language provided unprecedented opportunity for English practitioners, curriculum designers and material developers to engage with multiple programmes of English that cater for different learners (Murata and Jenkins 2009; Graddol et al. 2007). However, according to Fang and Yuan (2011), Jenkins (2014) and Crystal (1997), various models and approaches of teaching and learning English have remained focused on the native speaker standards despite the increase in the numbers of non-native English language users.

Kaplan (1993: 3) explains, "the language situation is essentially not well understood ... an element of chaos exists in the various sectors that deal with language... concerns have, to some degree, been offset by a residual racism... by the mistaken belief that English is the only language necessary for development". However, Baker (2015a), Wang

1 Kontakt podaci (Email): hkhatib@aou.edu.lb 
(2013) and Cogo (2012) observe that despite changes in the sociolinguistic landscape of the English language and the increased number of non-native English speakers, TEFL programmes still reflect the dominance of native English speaker norms.

In his study, Graddol (2010) estimated that non-native English language users have reached an unprecedented spread that exceeds one billion. According to Crystal (2012), eighty-five percent of the international organizations now use English as their working language.

This internationalization of English indicates the emergence of new needs for communicators that may differ from native speakers' norms. Ricento (2015), Saraceni (2015) and Houghton, and Melino (2015) propose that this increase in the number of non-native users of English can pose fundamental challenges to the established curricula and TEFL programmes.

In the past, TEFL assumed a centripetal cultural objective, drawing on western perspectives in EFL curricula (Pennycook 2007; Sharifian and Palmer 2007). In contemporary times, Sharifian (2011) and others warn that the extent to which local cultures remain disregarded in the expanding context of teaching English is starting to create negative discernments in learners. Nonetheless, the teaching of English curricula in non-English speaking regions continues to ignore the raised concerns (Kachru 1992; Graddol 2010; Block and Cameron 2002). In recent attempts, pedagogic interest in global Englishes, albeit at the theoretical level, has brought to focus calls on the need to review TEFL curricula (Houghton and Melino 2015; Archibald et al. 2011; Sharifian 2011).

\section{CONTEMPORARY ENGLISH MODELS}

Attempts at updating English language curricula have resulted in EFL, ESL, EAL and more recently EIL models, which exhibit different facets of the ELT enterprise. TESOL (teaching English to speakers of other languages) is the American term used to include TEFL (teaching English as a foreign language) and TESL (teaching English as a second Language), while ELT (English language teaching) is the terminology used in the British context where TESOL is perceived to have negative connotative and associated meanings.

The shifting tendencies in teaching English are oscillating between structural syllabuses and situational methods (Larsen-Freeman 2007; Baumgardner and Brown 2003). Policies and practices have concentrated on teaching a standard curriculum, notwithstanding the various contexts of use (Hennebry 2014). However, on the one hand, the structural syllabi remained focused on generic content without tailoring material to the sociolinguistic context. On the other hand, the situational methods did not target TEFL practice in preparing applicants and enabling them to relate theory to practice (Evans and Esch 2013; Graham et al. 2014). In both approaches, the dominance of native speaker norms in ELT and TEFL curricula did not appear to take account of the learners' needs and expectations in the Expanding Circle (Ricento 2015; Saraceni; 2015).

In a plenary presentation at SOAS - University of London, Itesh Sachdev on 26 June 2015 argued that education remains a site of oppression and transgression and called for revisiting the pedagogy of languages. Baker (2012) maintains that a holistic approach 
to language teaching cannot overlook the views of participants and practitioners. McKay (2002) contends that the nature of teaching and learning an additional language has to be tailored to the needs of the learners. However, Pennycook (2007) proposes that contemporary theories on language acquisition need to consider the global context of teaching and learning English and reflect cultural aspects from the learners' context. On the other hand, in a more focused scrutiny, Sharifian (2011) suggests that the extent to which theories and applications pave the way for reciprocal intercultural communications and molded identities needs to be reflected in TEFL programmes.

As for material preparation, McGroarty (2004) argues that developing curricula is a complex undertaking that needs to address multiple requirements. However, Pratt (1994) proposed that investigating curriculum options should critically explore and assess the rationale for studying the specific programme, the professional standards and expectations associated with the curriculum, its relevance to other curricula offered by competing programmes, and the learners' needs and expected learning outcomes.

In response to such views, a growing research interest is attempting to gain insight into practitioners' views on TEFL such as Baker (2015b), Fang and Yuan (2011), Cogo (2012) and others. However, cross referencing ELT and TEFL curricula in the Inner and Expanding Circles and triangulating insights from existing and potential candidates can inform such interest and provide an invaluable source for curriculum update or development. The current study is an attempt to reconcile learners' needs and perceptions in the Expanding Circle with TEFL and EFL curricula.

\section{THE CONTEXT OF THE STUDY}

The study is an attempt to critically assess the available MA in English programmes in the Expanding Circle context of Lebanon and compare them with programmes offered by universities in the native Inner Circle. The aim is to underline the specific fields that are indispensable to the success of teaching English within the socio-cultural non-native context of its users.

The context of the study concerns universities in one non-native EFL context in the Expanding Circle during the academic year of 2014 - 2015. The Expanding Circle, according to Kachru (1985) is the context where English is used as a foreign language, as opposed to the second language context of the Outer Circle of past colonies or the native context of the Inner Circle. The universities offer MA in TEFL programme to students who are interested in pursuing a teaching career in English at an advanced level.

Curricula from universities offering similar programmes are cross referenced in the Inner and Expanding Circle contexts to identify essential and variable components from a sociolinguistic perspective, based on the needs of the learners in the context of use. In addition, feedback from past MA graduates from various universities in Lebanon as well as potential MA candidates are triangulated to identify essential and variable components from participants' perspective. Participants were aware of the case study and were eager to take part in it. Participants' views were sought on two occasions: through questionnaires distributed to all, and through random interviews. 
Questionnaires were used to pursue patterns that can reveal a specific trend. The emerging indicators were later probed into through qualitative interview data to ratify or disprove the evolving assumptions. Therefore, the study draws on Mixed Method Research (MMR) comprising curricula evaluation, questionnaires and interviews.

Participants consisted of 21 senior English major students who are potential candidates for the MA in TEFL programme and 32 TEFL instructors from various Lebanese universities. Senior students are in their final year of completing BA in English Language and Literature and TEFL instructors hold at least MA degree in TEFL.

\section{ENGLISH LANGUAGE TEACHING IN THE INNER AND EXPANDING CONTEXTS}

\subsection{The Lebanese context}

In the Lebanese context, western-affiliated universities offer competing English programmes, which, "provide a solid background in British, American and other Anglophone literary texts, traditions and culture". (AUB catalogue, 2014-15: 220). The first sample university in Lebanon offers MA in English and MA in TEFL.

MA in English is more oriented towards the specialization component and offers 21 credit hour courses, in addition to a comprehensive examination and a thesis. The compulsory courses are structured around 12 credits of research methodology; sociolinguistics; theoretical linguistics or phonology; and language acquisition. The electives of 9 credits are designed around pedagogic and contemporary components covering such themes as principles and practices of teaching reading and literature; principles and practices of teaching writing and composition; seminars in TEFL; and World Englishes; issues in applied linguistics and grammatical studies in old and middle English literature. MA award is conditional to the successful completion of a thesis of 9 credits in addition to a comprehensive exam (see Table 1 below).

MA in Education with a concentration in TEFL has two options: thesis track and nonthesis track. Thesis track has 21 credits and a thesis. The non-thesis track has 33 credits and a project. The compulsory courses to both tracks are 6 credits comprising education psychology and research methods. The elective course is selected from 7 education courses comprising curriculum theory and design; educational planning; comparative education; Arab education; history and philosophy of education; determinants of educational policy; and comparative study of education in Arab countries. TEFL concentration courses cover 9 credits comprising: principles and practices of teaching reading and literature; principles and practices of teaching writing and composition; and seminar in TEFL. Thesis option has 9 credits allocated to thesis and an additional 3 credit course pertaining to the students' chosen area of specialization. The non-thesis option requires the completion of a 3 credit MA project and 12 credits from a selection of pedagogic courses ranging from theory and methods of testing; theory and design of curriculum; professional development in education; and curriculum and methodologies in elementary education language arts (see Table 1 below). 
Table 1: MA programmes in the first sample university in Lebanon

\begin{tabular}{|c|c|}
\hline $\begin{array}{l}\text { MA in English } \\
\text { MA in English can be completed through: } \\
\text { - } 21 \text { credit hours in courses } \\
\text { - Thesis ( } 9 \mathrm{cr}) \\
\text { - Comprehensive exam ( } 0 \mathrm{cr})\end{array}$ & $\begin{array}{l}\text { MA in Education - TEFL } \\
\text { MA in Education with a concentration on } \\
\text { TEFL can be completed through two options: } \\
\text { - Thesis track which includes completion } \\
\text { of } 21 \text { credits and a thesis, and } \\
\text { - Non-thesis option which includes a } \\
\text { minimum of } 33 \text { credits and a project }\end{array}$ \\
\hline $\begin{array}{ll}\text { Compulsory Courses } \\
\text { - } & \text { Introduction to bibliography and } \\
& \text { research methods ( } 3 \mathrm{cr} \text { ) } \\
\text { - } & \text { Sociolinguistics ( } 3 \mathrm{cr} \text { ) } \\
\text { - } & \text { Phonology ( } 3 \mathrm{cr} \text { ) or Theoretical } \\
& \text { linguistics }(3 \mathrm{cr}) \\
\text { - } & \text { Language Acquisition ( } 3 \mathrm{cr})\end{array}$ & $\begin{array}{l}\text { Compulsory Courses } \\
-\quad \text { Advanced psychology of education ( } 3 \mathrm{cr} \text { ) } \\
\text { - General research methods in education } \\
\quad(3 \mathrm{cr}) \\
\text { The balance of the programme comprises } \\
\text { primarily specialization courses related to } \\
\text { the student's chosen area of specialization }\end{array}$ \\
\hline 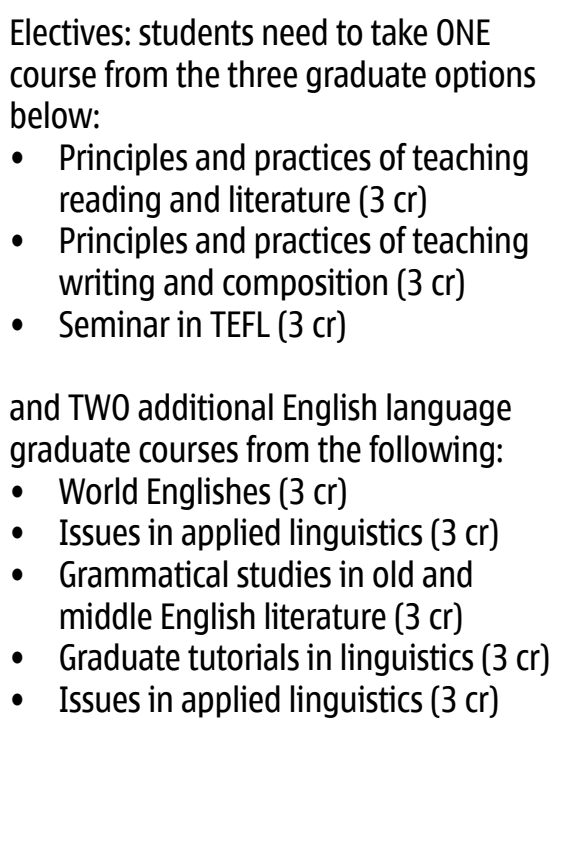 & 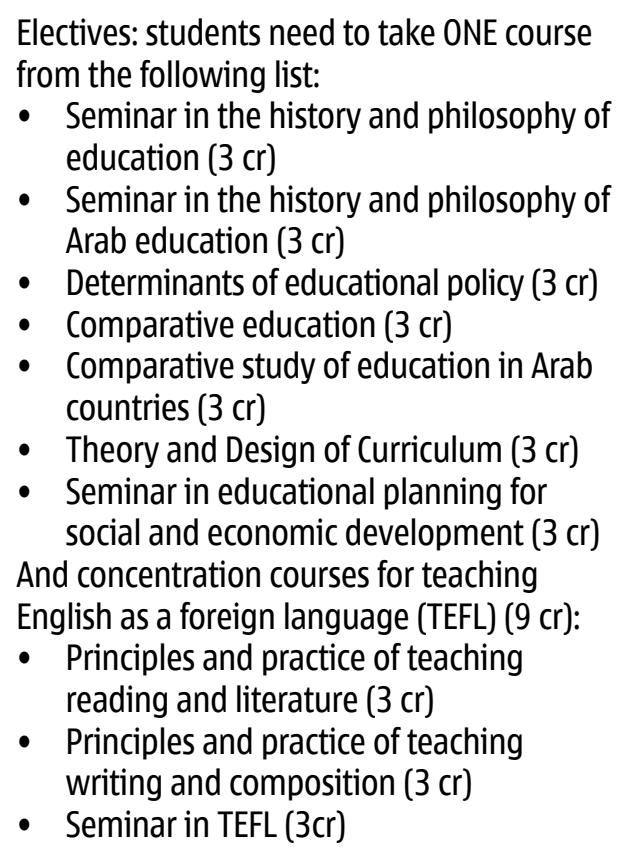 \\
\hline $\begin{array}{l}\text { MA thesis ( } 9 \mathrm{cr} \text { ) } \\
\text { Comprehensive exam }(0 \mathrm{cr} \text { ) }\end{array}$ & $\begin{array}{l}\text { MA thesis, or } \\
\text { MA project and additional options to } \\
\text { complete } 33 \text { required credits: } \\
\text { - Theory and methods of testing }(3 \mathrm{cr}) \\
\text { - Theory and design of curriculum ( } 3 \mathrm{cr} \text { ) } \\
\text { - Professional development in education } \\
\text { ( } 3 \mathrm{cr} \text { ) } \\
\text { - Curriculum and methodologies in } \\
\quad \text { elementary education language arts }(3 \mathrm{cr})\end{array}$ \\
\hline
\end{tabular}


The MA in English programme is structured around applied linguistics themes of sociolinguistics and language acquisition, theoretical linguistics themes and thesis writing courses. Pedagogic components feature in the elective courses. MA in education with TEFL concentration is structured around education courses and research methods. Concentration courses feature pedagogic components.

Sample two university in Lebanon offers MA in education with emphasis on the teaching of English to speakers of other languages (TESOL). MA in Education with TESOL comprises 9 credits of education oriented courses encompassing curriculum design; advanced education psychology and educational technology; and 3 credits on research methods. The elective course is selected from 7 education courses on trends and issues in early and middle childhood education; special education for all educators; behaviour modification techniques; trends and issues in teaching, learning and assessment; educational policies and social impact. Concentration courses cover 9 credits in trends and issues in TESOL; sociolinguistics and social contexts of languages; and discourse and material development. The university offers thesis option of 6 credits or research project of 3 credits in addition to another elective course of 3 credits to complete the 30 credits required for attaining the MA in Education with TESOL (see Table 2 below).

Table 2: MA in Education with TESOL in sample two university in Lebanon

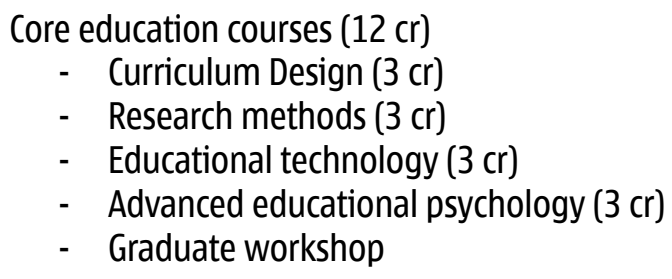

Electives: students have to take one course from the following options:

- Trends and issues in early and middle childhood education (3 cr)

- Special education for all educators (3 cr)

- Behavior modification techniques (3 cr)

- Trends and Issues in teaching, learning and assessment (3 cr)

- Educational policies and social impact (3 cr)

Emphasis courses ( $9 \mathrm{cr}$ )

- Trends and Issues in TESOL (3cr)

- Sociolinguistics and Social contexts of languages (3 cr)

- Discourse and material development (3 cr)

$$
\text { Capstone (6 cr) }
$$

Students can either do a

Research project $(3 \mathrm{Cr}$ ) and One elective course $(3 \mathrm{cr})$

$\underline{\mathbf{O R}}$

Thesis in education $(6 \mathrm{cr}$ )

To complete the required 30 credits at Master's level 
The MA in Education with TESOL concentration programme is structured around education courses and research method. The emphasis courses feature applied linguistics courses and material development

\subsection{The British context}

Sample three university in the Inner Circle offers MA in English Language Teaching (ELT) and MA in Applied Linguistics (MAAL). According to the programme leader interviewed on 4 May 2015, both programmes are structured around applied linguistics components, pedagogic components and research components. Concentration courses are tailored around the requirements from the field of specialty.

MA in ELT has compulsory specialization modules comprising descriptive English grammar and English phonology. For taught and dissertation track the mandatory modules are: discourse analysis for language teachers; second language learning principles and language curriculum design. For the portfolio track, the mandatory courses comprise: core issues in language teaching; second language teaching and learning and teaching the language skills. For the dissertation track, research design and a dissertation component of 60 credits need to be completed; while for the portfolio track, a language teaching portfolio component of 60 credits needs to be submitted. Three elective courses need to be selected from a variety of pedagogic and specialization courses for dissertation or portfolio track and six courses if students follow the taught and dissertation track to accumulate the 180 credits required for completing the MA programme. For the taught and dissertation track, the option modules are selected from a variety of pedagogic and specialization courses comprising: child language development; English for specific purposes; English in the world; language curriculum design; corpus-based approaches to language description; written language (Reading and Writing); issues in bilingualism; spoken language (Listening and Speaking); language testing principles; information technology for language teaching; teaching young learners; and the teaching and learning of vocabulary. For the portfolio track, the option modules are: child language development; English for specific purposes; English in the world; issues in Bilingualism; corpus based approaches to language description; language testing principles; information technology for language teaching; teaching young learners; and the teaching and learning of vocabulary (see Table 3 below).

As for MA in Applied Linguistics (MAAL), the compulsory modules are offered in the areas of language description, language pedagogy and language learning. The compulsory modules comprise: discourse analysis for language teachers; English phonology; descriptive English grammar; second language learning principles; sociolinguistics; research design and dissertation. Three elective courses need to be selected from a variety of pedagogic and applied linguistics courses: child language development; English for specific purposes; English in the world; language curriculum design; corpus-based approaches to language description; psycholinguistics; written language (Reading and Writing); issues in bilingualism; spoken language (Listening and Speaking); language testing principles; information technology for language teaching; teaching young learners; and the teaching and learning of vocabulary (see Table 3 below). 
Table 3: Inner Circle programmes MA in ELT and MAAL

\begin{tabular}{|c|c|}
\hline MA in English Language Teaching (ELT) & MA in Applied Linguistics (MAAL) \\
\hline $\begin{array}{l}\text { The compulsory modules are divided into the } \\
\text { following areas: } \\
\text { 1. English language description. } \\
\text { 2. Language teaching and learning } \\
\text { 3. Research or teaching observation and } \\
\text { practice portfolios. } \\
\text { In addition to } \\
\text { 4. The dissertation research ( } 15000 \text { words) } \\
\text { or language teaching portfolio }\end{array}$ & $\begin{array}{l}\text { The compulsory modules are } \\
\text { offered in the following areas: } \\
\text { 1. English language description } \\
\text { 2. Language pedagogy and } \\
\text { 3. Language learning, within the } \\
\text { broad field of study of language } \\
\text { in use } \\
\text { In addition to } \\
\text { The dissertation research }\end{array}$ \\
\hline $\begin{array}{l}\text { The compulsory modules are the following: } \\
\text { - Descriptive English Grammar (10 cr) } \\
\text { - English phonology (10cr) } \\
\text { For taught and dissertation track } \\
\text { - Discourse analysis for language } \\
\text { - teaches ( } 10 \mathrm{cr} \text { ) } \\
\text { - Second language learning principles } \\
\text { (20cr) } \\
\text { - Language curriculum design (10cr) } \\
\text { For portfolio track: } \\
\text { - Core issues in language teaching } \\
\text { - }(10 \mathrm{cr}) \\
\text { - } \text { learning (10cr) } \\
\text { For deaching the language skills (10cr) } \\
\text { - Research design and dissertation (60 } \\
\text { cr) } \\
\text { For portfolio track: } \\
\text { - Language teaching portfolio (60cr) }\end{array}$ & $\begin{array}{l}\text { The compulsory modules are SIX: } \\
\text { - Discourse analysis for language } \\
\text { teachers }(10 \mathrm{cr}) \\
\text { - English phonology }(10 \mathrm{cr}) \\
\text { - Descriptive English Grammar } \\
(10 \mathrm{cr}) \\
\text { - Second language learning } \\
\text { principles ( } 20 \mathrm{cr} \text { ) } \\
\text { - Sociolinguistics }(10 \mathrm{cr}) \\
\text { - Research design and } \\
\text { dissertation }(60 \mathrm{cr})\end{array}$ \\
\hline
\end{tabular}




\begin{tabular}{|c|c|}
\hline MA in English Language Teaching (ELT) & MA in Applied Linguistics (MAAL) \\
\hline 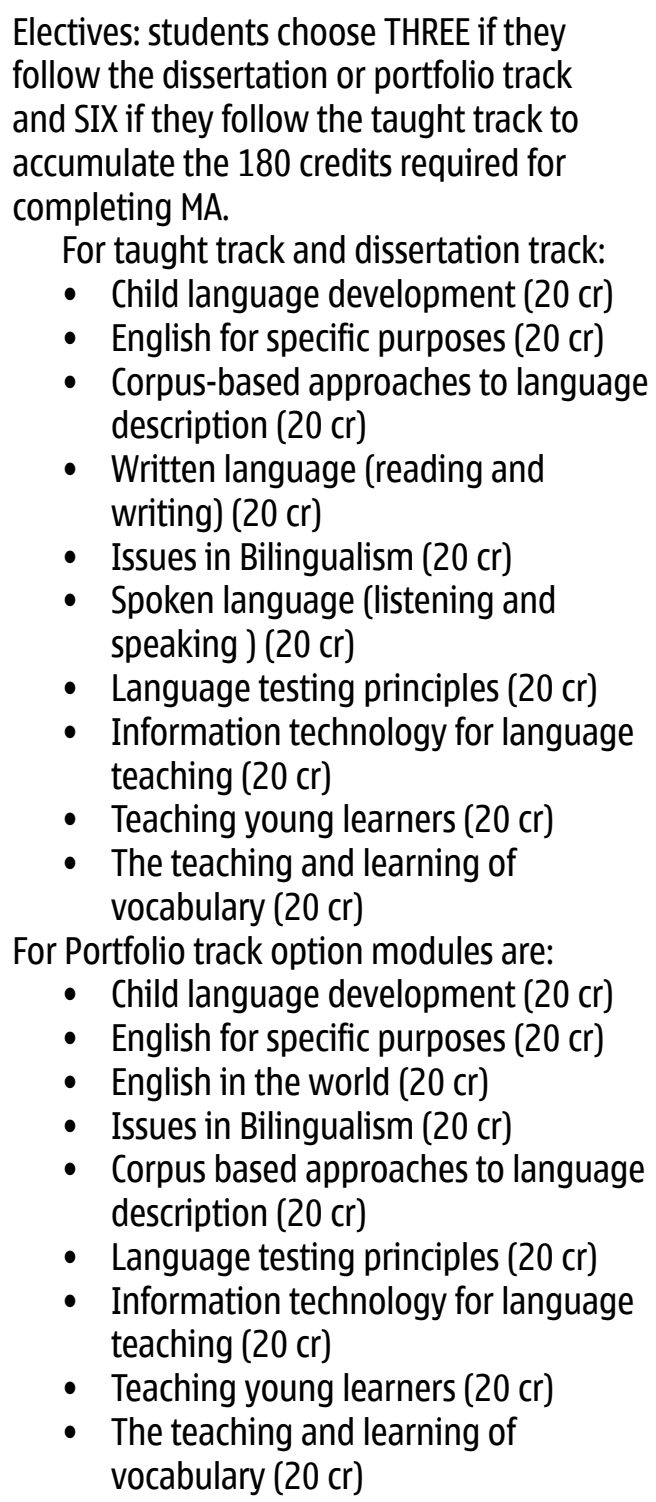 & 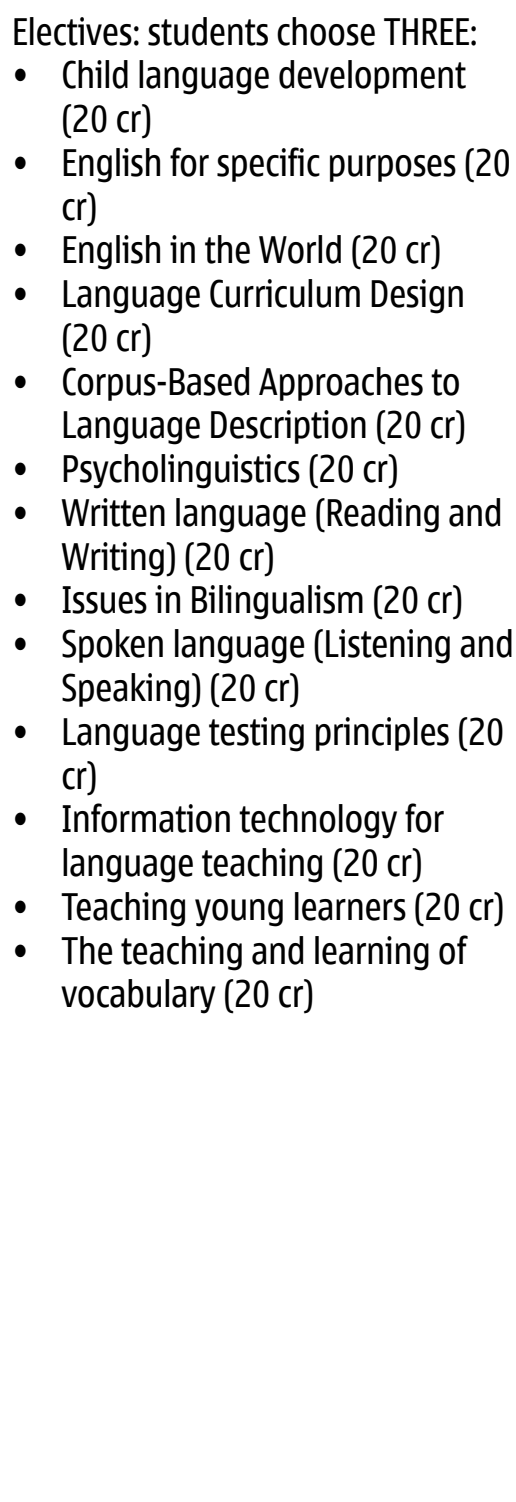 \\
\hline
\end{tabular}

It follows from the above that English specialization programmes offered by universities in the Inner and Expanding Circles maintain comparable theoretical and applied linguistics components and pedagogic and educational orientations, depending on the offered specialization. However, on matters pertaining to the local context, the MA programmes offered by leading universities in the Expanding Circle of the Lebanese context follow the set components of the programmes offered by universities in the native Inner Circle. 
While in the Expanding Circle, the design of the TEFL curriculum needs to recognize the linguistic aspect of the specialization, the pedagogic aspect of the profession and the cultural aspect of the context, only the MA in Education with TEFL concentration has two courses pertaining to the local context, among the elective list of seven; out of which students choose only one.

Following this overview of programme components, participants' views and expectations are sought in relation to their perception on the offered programmes.

\section{PARTICIPANTS' PERSPECTIVES}

Learners' views are sought through questionnaires and feedback sessions on the perceived needs and expectations. The research was carried out in the Fall and Spring semesters of 2014 - 2015. Participants consisted of 21 final year students who were completing BA in English Language and Literature in Lebanon as well as 32 TEFL instructors from various Lebanese universities. The senior students ages ranged between $22-24$ years and were 8 males and 13 females. The TEFL instructors have at least MA degree in TEFL from prominent universities in Lebanon, their ages ranged between 34 to 48 years and were 6 males and 26 females.

The questionnaires comprised Likert scale on 15 items encompassing views on programme utility, components and learners' perceptions. Feedback sessions were arranged with participants after the questionnaires were completed, to exchange views and elaborate on responses. Anonymity was offered but respondents were eager to contribute to the study.

The study showed that motivational orientations were identified first by the two groups as the primary reason for learning TEFL; an attestation to the persistence of English as an important international language with economic and social values in the Expanding Circle.

Senior students who are potential candidates for the MA in TEFL programme unanimously agreed that MA in TEFL would help them improve future career, improve subject knowledge and help them gain professional practice in teaching. Eighteen students agreed that MA in TEFL would help them use English appropriately in different social contexts while two were uncertain.

Six students agreed that TEFL curriculum should be solely focused on teaching English language rules while five were uncertain and ten disagreed. Eight students agreed that TEFL curriculum needs to focus on British or American context, five were uncertain and eight disagreed.

Four students agreed that TEFL programme should include aspects from English history and development, while six were uncertain and eleven disagreed. Eighteen students agreed that TEFL programme should target theories of teaching and learning English, while three were uncertain. Nineteen students agreed that TEFL programme should identify problems that Arab learners face and provide solutions, while two were uncertain. Eighteen students agreed that TEFL should include a sociolinguistic component while two students were uncertain and one disagreed. 


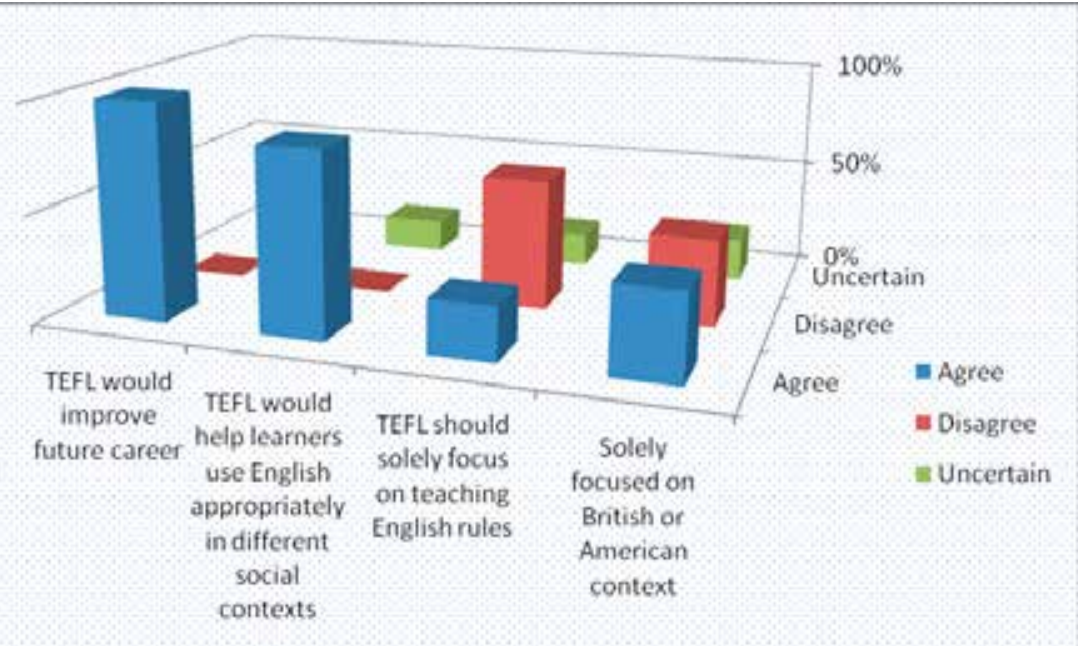

Figure 1: Senior students' perceptions on TEFL programme

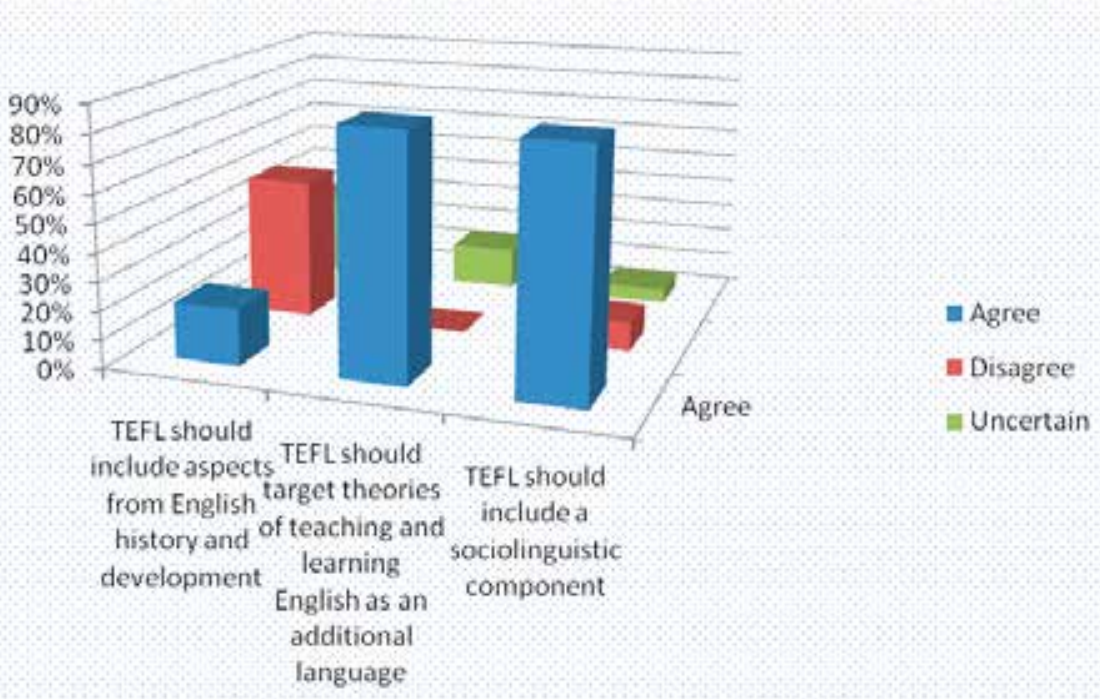

Figure 2: Senior students' perceptions on TEFL components

Seventeen students agreed that TEFL programme needs to be relevant to the learners' context and four were uncertain. Seventeen students agreed that TEFL programme needs to include aspects from the learners' culture and four were uncertain. Four students agreed that TEFL curriculum should focus on aspects from the target culture, nine were uncertain and eight disagreed. 


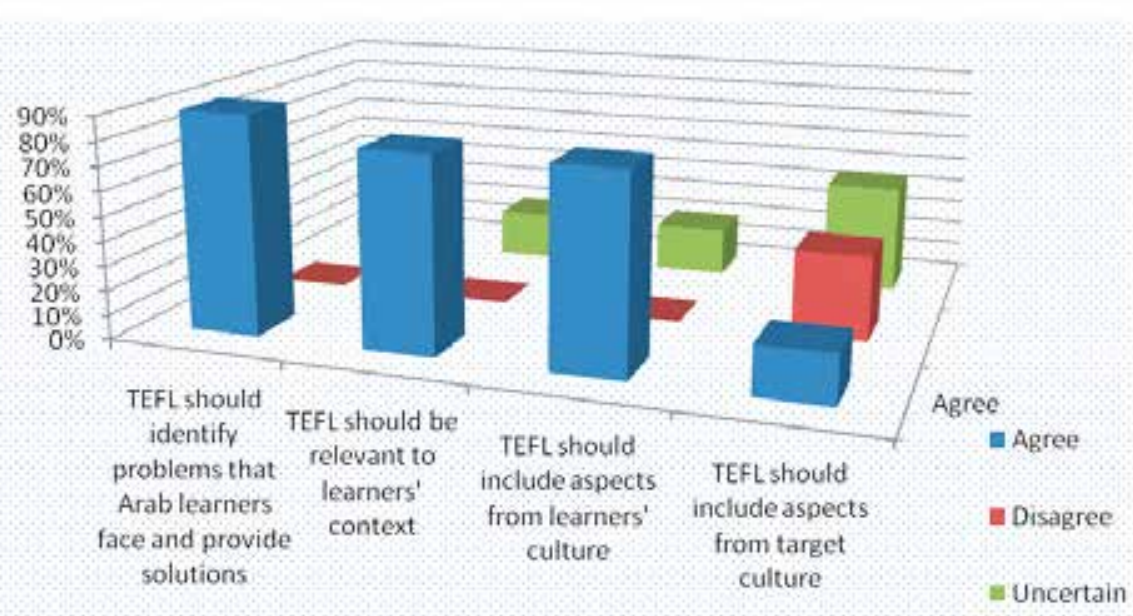

Figure 3: Senior students' perceptions on TEFL relevance to local context

Six students agreed that TEFL curriculum needs to be similar to other curricula offered by universities of the native Inner Circle, two were uncertain and thirteen disagreed. Eighteen students agreed that TEFL curriculum needs to be similar to other curricula offered by other local universities, while three were uncertain.

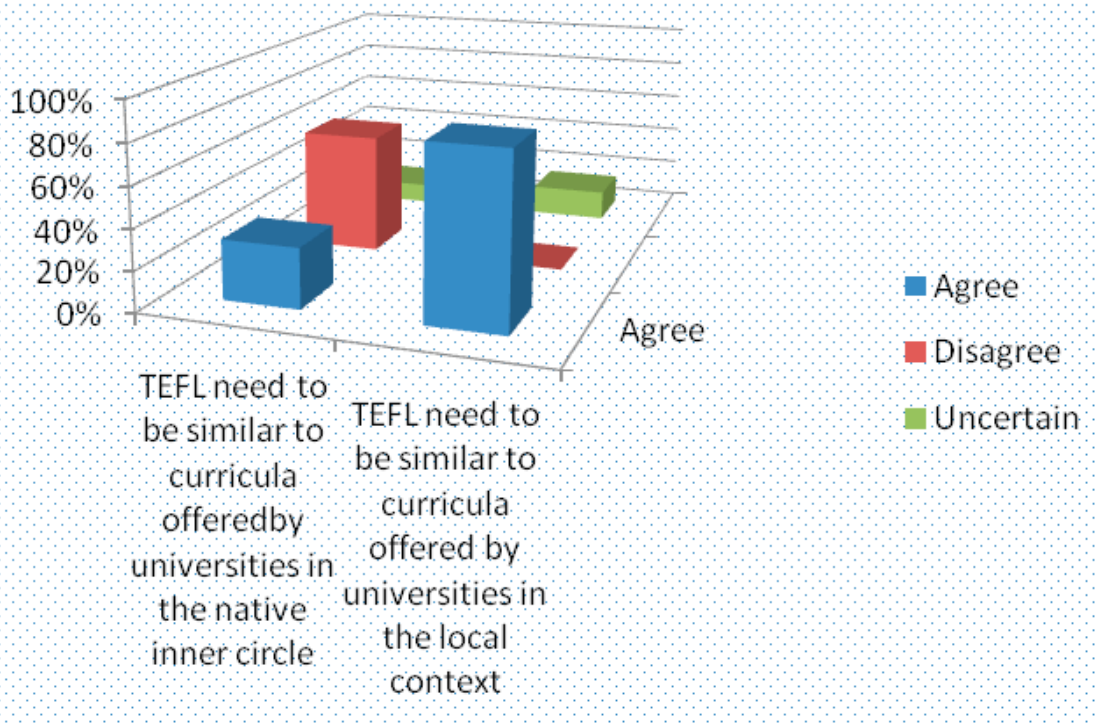

Figure 4: Senior students' perceptions on TEFL similarity to programmes in the Inner and Expanding Circles 
As for MA graduates' feedback, MA graduates unanimously agreed that gaining MA in TEFL helped them get better jobs. Fifty percent of MA graduates agreed that MA programme provided adequate subject knowledge to teaching English in a foreign language context and fifty percent were uncertain. As for pedagogic knowledge of teaching English in a foreign language context, twenty-six agreed that MA programme provided this; six were uncertain. One commented that some specific courses helped but not all.

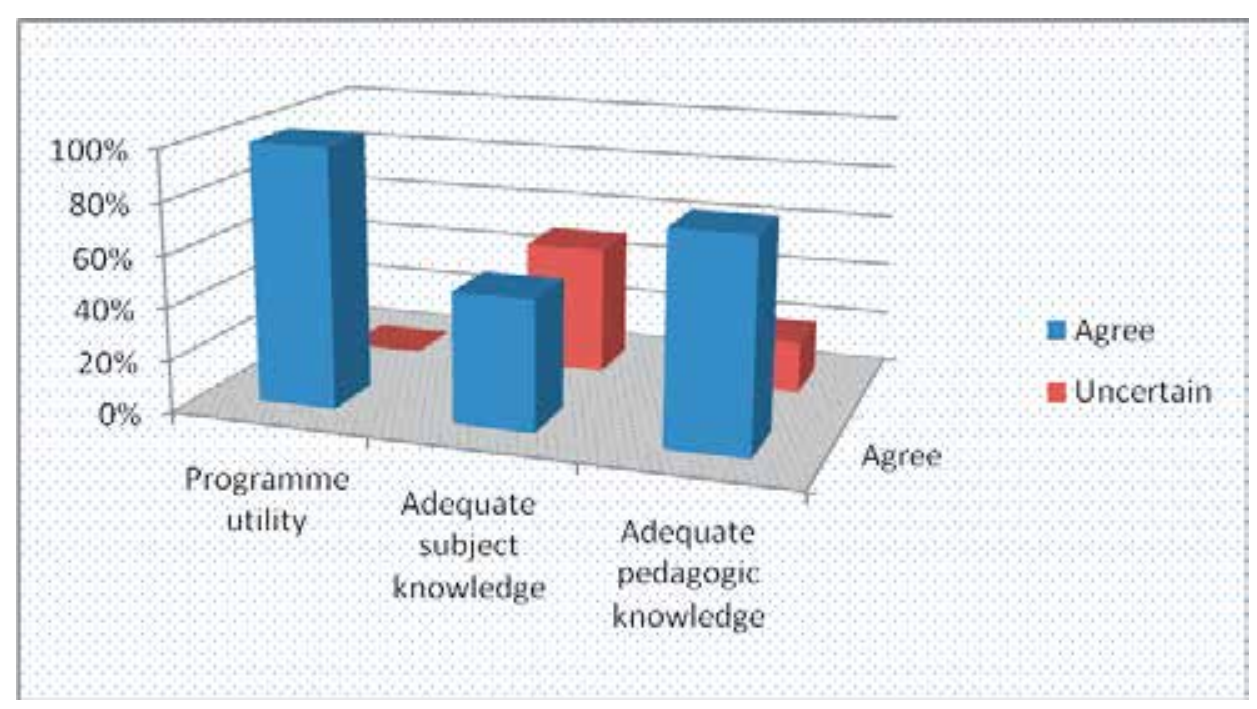

Figure 5: MA graduates' feedback on TEFL programme

Twenty-three participants agreed that MA programme provided unnecessary Anglophone cultural items and nine were uncertain. As for reference to local culture, nine participants strongly agreed and thirteen agreed that MA programme lacks reference to local culture, while nine were uncertain. Nine participants strongly agreed and thirteen agreed that the programme should include more reference to local culture, while nine were uncertain. 


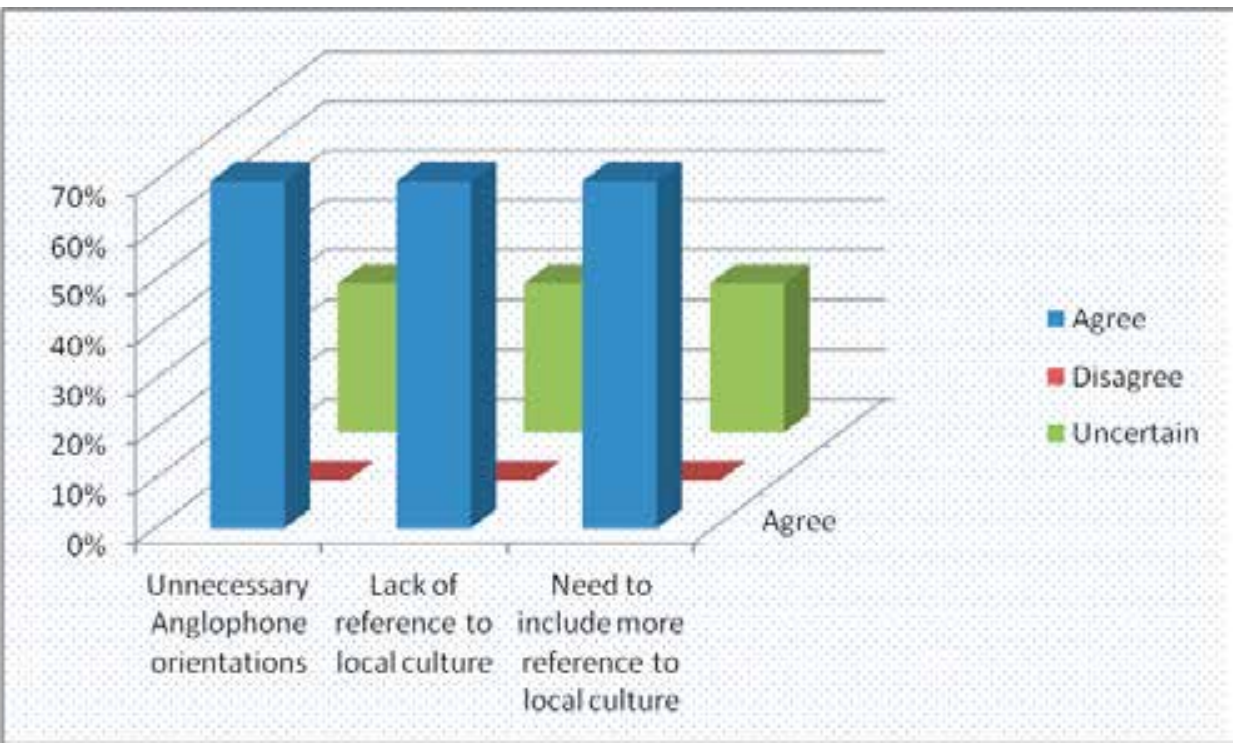

Figure 6: Reference to Anglophone and local cultures

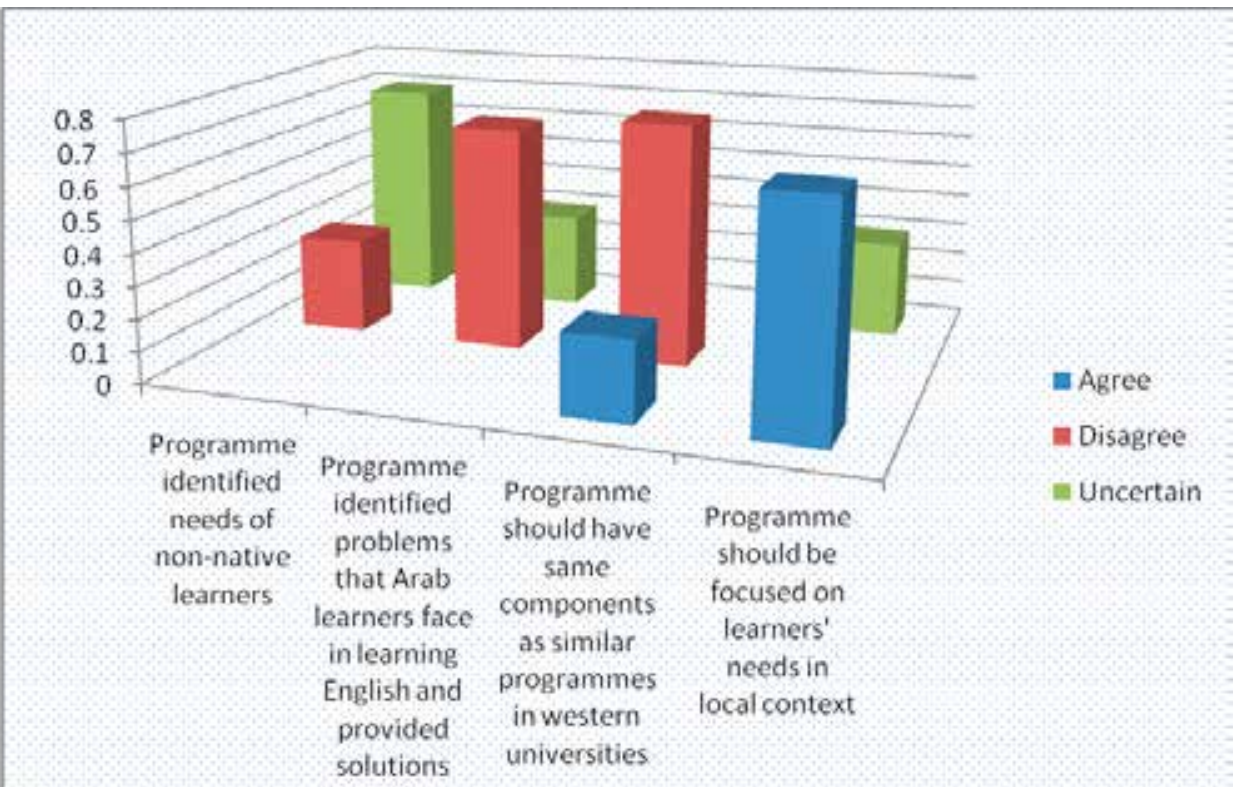

Figure 7: TEFL programme and learners' needs

Twenty-three participants were uncertain whether the programme identified the needs of non-native learners and nine participants did not think that it did. Twenty-three participants did not think that the programme identified the problems that Arab learners 
face in learning English nor provided solutions to their difficulties while nine participants were uncertain. Twenty-three participants agreed that the programme should be focused on learners' needs in the local context, while nine were uncertain. Eight participants perceived that the MA in TEFL curriculum should have the same components offered in the universities of the native inner circle, while twenty-four participants disagreed.

All participants strongly agreed or agreed that a thesis component should be included in the MA programme; twenty-three participants disagreed that a working portfolio can replace a thesis in the MA programme, while nine commented that this would depend on whether MA is vocational or academic.

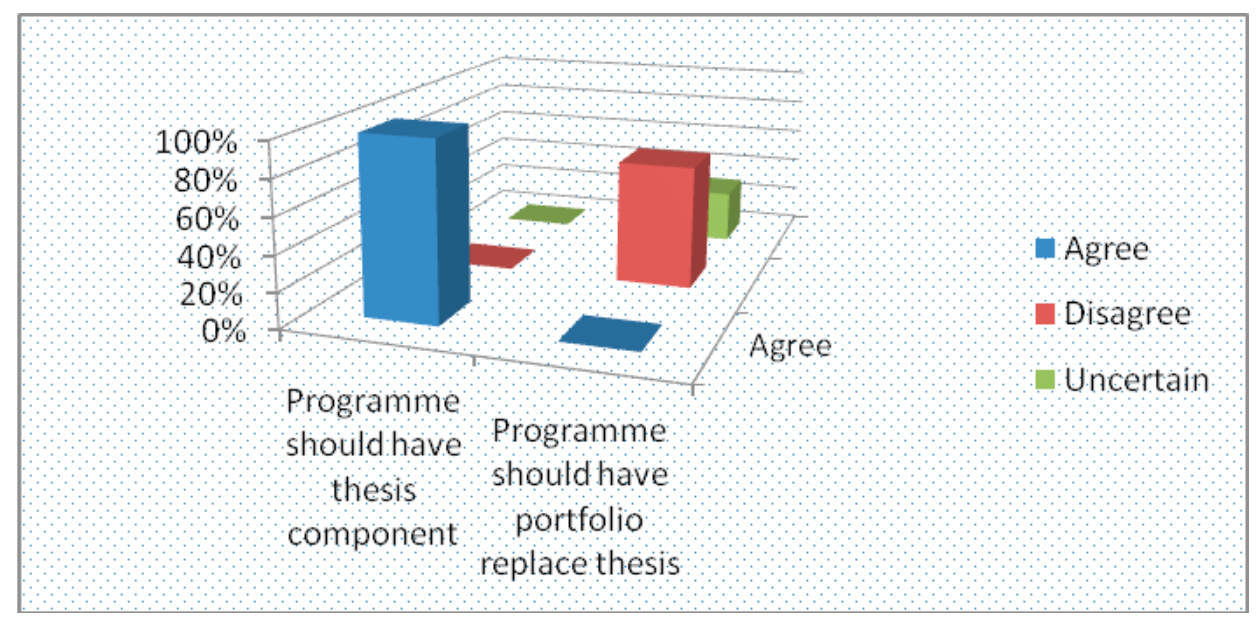

Figure 8: Thesis or Portfolio

\section{TEFL IN THE EXPANDING CIRCLE}

According to Nunan (2012), a useful programme needs to reflect the values, principles and purposes of the curricula, represent current thinking, reflect the needs of learners, help learners understand the targeted qualification, and provide recognition of areas of learning that can contribute to learner's personal development and future goals. As reflected in senior students' feedback (cf. Figure 1), teaching English is perceived to involve not only English language rules, but also sociolinguistic and cultural components that can help learners discern meaning from various regional and international contexts even when the words, grammar or phrases differ from the English they were taught. In this respect, TEFL curricula need to embrace contemporary research findings on English in the global context and acknowledge the more complex views on interculturality and communication in English. Moreover, TEFL needs to reflect the goals of mainstream education in the various local contexts and satisfy the professional requirements for the desired career.

Senior students who are potential candidates for the MA in TEFL programme expected the programme to exhibit relevance to the local culture as well as target the 
problems that Arab learners face, within the pedagogic themes of teaching and learning, and provide solutions. Most senior students perceived that the MA in TEFL should match the values and principles of similar curricula offered by local universities and few opted for similar curricula to Inner Circle programmes.

As for MA graduates' feedback, and in terms of Nunan's categories, the programmes outlined above all reflect linguistic components, pedagogic components and have a research component. However, in terms of satisfaction with adequate subject knowledge, an alarming fifty percent of learners who have completed contemporary TEFL programmes expressed agreement that MA in TEFL provided adequate subject knowledge to teaching English in a foreign language context. In the feedback sessions, respondents who were uncertain of whether the offered TEFL programmes provided adequate subject knowledge to teaching English in a foreign language context commented that the programme would benefit from an applied comparative linguistic component that addresses the particular difficulties that learners face in the specific discourse community.

MA graduates with long experience of teaching English in the Expanding circle context of Lebanon commented that MA in TEFL programme of study should incorporate error analysis component to identify the sources of errors in syntax, vocabulary and pronunciation that are associated with the influence of the specific first language. This component varies from one Expanding Circle context to another. Identifying inappropriate mapping of grammar patterns according to first language rules and specific pronunciation difficulties as well as confusing vocabulary items within the category of false friends should help future tutors of English anticipate their students' potential difficulty areas and provide the appropriate solutions. Feedback from MA graduates also acknowledged cultural differences in communication styles as an area worthy of targeting in a TEFL programme.

Participants provided illustrative examples that demonstrated that the difficulties faced by Egyptian Arab learners, for example, are not the same as those faced by Lebanese Arab learners and this indicates the need for even finer tuning of the TEFL programme to regional difficulties within an ideologically perceived standard variety. An applied comparative linguistic component within a TEFL programme can help raise awareness on the specific phonological, syntactic and morphological difficulties impacting learners in a special ethnolinguistic group.

Comparative analysis can help future tutors draw the attention of learners to ways of overcoming the identified difficulties and this can prove to be a more useful component than mere identification of the properties of English and its size of lexicon and history. Reference to local culture needs to substitute the perceived unnecessary Anglophone orientations and the programme needs to be tailored to learners' needs in the learning contexts.

\section{CONCLUSION}

The spread of English through globalization as the main international language provided unprecedented opportunity for English practitioners to develop material and diversify methods to cater for foreign language learners in various communication venues. 
While English native language users were estimated to be 375 million speakers (Crystal 1997), English second language users reached the same number (375 million in 2000) and EFL users were estimated to be in the area of one billion speakers (Graddol 2010).

New working practices in global media, business, international forums, entertainment, diplomacy, politics, finance, and others, indicate the emergence of different needs of international communicators using English and pose fundamental challenges to the complex topics of teaching English as a foreign language. While policies and practices have concentrated on teaching a uniform standard English, notwithstanding the various contexts of use, the Expanding circle contexts have confirmed the existence of local varieties of English.

Going back to our original research concerns on whether the "one size fits all" remains a valid argument in teaching English (Graddol et al. 2007) and in the wake of the changing concerns of English language users in the Expanding Circle context, as underlined by participants in this case study, we find a need to revisit existing TEFL models and apply a user-based perspective to them. Seidelhofer (2011) maintains that English language users in the Expanding Circle are not mere recipients and dependent followers of native speaker norms and techniques. English language users in the Expanding Circle are adapting rather than adopting the English language and customizing it according to their needs. Fang and Yuan (2011) call for original models of English in the Expanding Circle context that would allow for indigenous values, culture and logic that may not be easily expressed with the Inner Circle models.

The future of TEFL in the non-native contexts of the Expanding Circle will maintain the essential linguistic component shared with programmes in the Inner Circle, however an additional upgrading is recommended towards international English, given the pluralistic context and the neo-eclectic trends in contemporary research.

In terms of whether or not native cultural elements need to be maintained in the TEFL curriculum, there is a need to expand the cultural component to include variable elements from the local context (Lantolf and Thorne 2006). An applied variable ethnolinguistic component (Underhill 2012; Giles and Johnson 1987) can draw on the characteristics and needs of the specific discourse community using English (Nunan 2012), and tailor the teaching model to address the specific concerns of each (Hulstijn and Ellis 2005). The one size fits all model provides a general framework that is not sufficient to relate the prescribed model to the particularities of the user community.

The cultural pedagogic component introduces culturally appropriate teaching models and draws attention of learners to different teaching and learning styles of international users of English in the global context (Jensin 2009). Future teachers need to be culturally oriented to acknowledge various teaching and learning models that would enrich their future experience.

In the words of Abraham Lincoln (1862), "the dogmas of the quiet past are inadequate to the stormy present. The occasion is piled high with difficulty, and we must rise with the occasion. As our case is new, so we must think anew and act anew".

The TEFL model has overstayed its time. The general areas of concern that it has introduced can no more be sufficient to the international arena of users. Persistence in using it can only support centripetal trends that consider "native" English as the norm and the target of learning. The need for language users in the international 
context, for studying and teaching English in their discourse communities, would benefit from a more ethnolinguistic and culturally rich English as an International Language teaching model.

\section{REFERENCES}

Archibald, A., A. Cogo and J. Jenkins (eds.). 2011. Latest Trends in ELF

Research. Newcastle: Cambridge Scholars. American University of Beirut academic catalogue, 2014-15.

Baker, W. 2015a. Culture and complexity through English as a lingua franca: Rethinking competence and pedagogy in ELT. Journal of English as a Lingua Franca 4 (1). 9-30.

Baker, W. 2015b. Culture and Identity through English as a Lingua Franca: Rethinking Concepts and Goals in Intercultural Communication. Berlin: Mouton de Gruyter.

Baker, W. 2012. Global cultures and identities. In Theron Muler, Steven Herder, John Adamson and Philip Shigeo Brown (eds.). Innovating EFL Education in Asia. Basingstoke: Palgrave Macmillan. 23-34.

Baird, R., W. Baker, and M. Kitazawa. 2014. The complexity of English as a Lingua Franca. Journal of English as a Lingua Franca, 3 (1). 171-196.

Baumgardner, R. and K. Brown. 2003. World Englishes: Ethics and pedagogy. Word Englishes, 22 (3). 245-251.

Block, D. and D. Cameron (eds.) 2002. Globalization and Language Teaching. London: Routledge.

Cogo, A. 2012. English as a Lingua Franca: Concepts, Use and Implications. ELT Journal 66 (1). 97-105.

Cogo, A. and J. Jenkins. 2010. English as a Lingua Franca in Europe: A Mismatch between Policy and Practice. European Journal of Language Policy 2 (2). 271-294.

Crystal, D. 1997. English as a Global Language. Cambridge: CUP.

Crystal, D. 2012. A Global Language. English in the World. Milton Keynes: The Open University.

Evans, M. and E. Esch. 2013. The Elusive Boundaries of Second Language Teacher Professional Development. The Language Learning Journal 41 (2). 137-141.

Fang, F. and M. Yuan. 2011. Globalized English in Asia, Now and the future. In Lawrence Zun Zhang, Rani Rubdy and Lubna Alsagoff (eds.). Asian Englishes: Changing Perspectives in a Globalized World. Singapore: Pearson. 93-118.

Giles, H. and P. Johnson. 1987. Ethnolinguistic Identity Theory: A Social Psychological Approach to Language Maintenance. International Journal of the Sociology of Language. 68. Amsterdam: Mouton de Gruyter. 69-100.

Graddol, D. 2000. The Future of English. London: British Council.

Graddol, D. 2010. English Next. The Future of English in India. London: British Council.

Graddol, D., D. Leith, J. Swann, M. Rhys and J. Gillen (eds.). 2007. Changing English. London: Routledge.

Graham, S., L. Courtney, T. Marinis and A. Tonkyn. 2014. Primary Modern Languages: the Impact of Teaching Approaches on Attainment and Preparedness. Final Report. University of Reading. 
Hennebry, M. 2014. Language Teaching for European Citizenship: Insights for Teacher Education. The Language Learning Journal 42 (3). 289-306.

Houghton, A. and P. Melino (eds.). 2015. Intercultural Communication and Language Education. London \& New York: Springer.

Hulstinjin, J. and R. Ellis (eds.). 2005. Theoretical and Empirical Issues in the Study of Implicit and Explicit Second Language Learning. Studies in Second Language Acquisition, 27 (2).

Jenkins, J. 2015. Global English. London: Routledge.

Jenkins, J. 2014. English as a Lingua Franca in the International University. The Politics of Academic English Language Policy. London: Routledge.

Jenkins, J. 2013. English in the Expanding Circle. In Markku Filppula, Juhani Klemola and Devyani Sharma (eds.) The Oxford Handbook of World Englishes. Oxford: OUP.

Jenkins, J., A. Cogo and M. Dewey. 2011. Review in Developments in Research into English as a Lingua Franca. Language Teaching 44 (3).

Jensin, A. 2009. Discourse Strategies. English for Specific Purposes, 28 (1). 4-18.

Kachru, B. 1992. The Other Tongue: English Across Cultures. Urbana: University of Illinois Press.

Kachru, B. 1985. Standards, Codification and Sociolinguistic Realism: the English Language in the Outer Circle. In Randolf Quirk and Henry Widdowson (eds.) English in the World. Cambridge: CUP, 11-30.

Kaplan (1993) cited in Diane Johnson. 2015. The Provision of European Languages in Anglophone Contexts. Scottish Languages Review 29. 41-54.

Lantolf, J. and S. Thorne. 2006. Socio-Cultural Theory and the Genesis of Second Language Development. Oxford: OUP.

Larsen-Freeman, D. 2007. Reflecting on the Cognitive-Social Debate in Second Language Acquisition. The Modern Language Journal, 91. 773-787.

Lincoln, A. 1862. Annual Message to Congress. Washington DC. 1 December.

McGroarty, M. 2004. Advances in Language Pedagogy. Annual Review of Applied Linguistics 24.

McKay, S. 2002. Teaching English as an International Language. Rethinking Goals and Approaches. 0xford: 0UP.

Murata, K. and J. Jenkins (eds.). 2009. Global Englishes in Asian Contexts. Basingstoke: Palgrave Macmillan.

Nunan, D. 2012. Communicative Tasks and the Language Curriculum. TESOL Quarterly 25 (2). 279-295.

Pratt, D. 1994. Curriculum Planning: A Handbook for Professionals. Fort Worth: Harcourt Brace College Publishers.

Pennycook, A. 2007. Global Englishes and Transcultural Flows. London \& New York: Routledge.

Ricento, T. (ed.) 2015. Language Policy and Political Economy: English in a Global Context. Oxford: OUP.

Saraceni, M. 2015. World Englishes: A Critical Analysis. London \& New York: Bloomsbury Academic.

Seidlhofer, B. 2011. Understanding English as a Lingua Franca. Oxford: OUP.

Sharifian, F. 2011. Cultural Conceptualizations and Language: Theoretical Framework and Applications. Amsterdam \& Philadelphia: John Benjamins. 
Sharifian, F. and G. Palmer (eds.) 2007. Applied Cultural Linguistics: Implications for Second Language Learning and Intercultural Communication. Amsterdam and Philadelphia: John Benjamins.

Underhill, J. 2012. Ethnolinguistics and Cultural Concepts. Cambridge: CUP.

Wang, Y. 2013. Non-Conformity to ENL Norms. Journal of English as a Lingua Franca 2 (2). 255-282.

Wierzbicka, A. 2010. Experience, Evidence and Sense: The Hidden Cultural Legacy of English. Oxford: OUP.

\section{SUMMARY}

\section{A CRITICAL ENQUIRY INTO TEFL: FROM ROOT ORIGINS TO THE NON-NATIVE CONTEXTS OF THE EXPANDING CIRCLE}

The study is a critical enquiry into TEFL from its root origins to one non-native context in the Expanding Circle. The article argues that despite changes in the sociolinguistic landscape of the English language (Hennerbry 2014; Wierzbicka 2010) and the increased number of non-native English speakers (Graddol 2010; Crystal 2012), English language teaching programmes in this case study remain heavily based on the propositions and models of the Inner Circle (Baird et al. 2014; Jenkins 2013).

While tracing the shifting tendencies in teaching English (Baker 2015a; Wang 2013; Cogo 2012), the study assesses English language teaching programme components in relation to learners' needs and learning objectives. In tracing the pedagogy and application of TEFL from roots to non-native contexts, the study confirms that recent pedagogic interest in global Englishes (Jenkins 2015; Baker 2012; Jenkins et al. 2011), albeit at the theoretical level (Ricento 2015; Saraceni 2015) did not seem to impact TEFL programmes and curricula in non-native contexts.

The context of the study includes universities in Lebanon where English is taught as TEFL and universities in Britain teaching English as ELT. Through mixed methods and triangulating feedback, past graduates and potential candidates confirm that the TEFL programmes offered in the non-native context of the Expanding Circle still reflect the dominance of native English speaker norms. In addition, the scrutiny of the offered programmes in the Inner and Expanding Circles confirms that MA Programmes in the Expanding Circle replicate to a large extent the native programmes offered in the Inner Circle. Aspects from local culture remain lacking and the language concerns of the local learner remain not targeted.

The study concludes with a set of propositions that frames TEFL curriculum within essential and variable components that underline specific fields for teaching English within the socio-cultural non-native context of its users. TEFL. 
Appendix One: Questionnaire for ELL Senior Students - potential candidates for MA in TEFL programme

\begin{tabular}{|c|c|c|c|c|c|}
\hline Item & $\begin{array}{l}\text { Strongly } \\
\text { agree }\end{array}$ & Agree & Uncertain & Disagree & $\begin{array}{l}\text { Strongly } \\
\text { Disagree }\end{array}$ \\
\hline $\begin{array}{l}\text { 1. TEFL will help me } \\
\text { improve future career }\end{array}$ & & & & & \\
\hline $\begin{array}{l}\text { 2. TEFL will improve subject } \\
\text { knowledge }\end{array}$ & & & & & \\
\hline $\begin{array}{l}\text { 3. TEFL will help me gain } \\
\text { professional practice in } \\
\text { teaching }\end{array}$ & & & & & \\
\hline $\begin{array}{l}\text { 4. TEFL will help me use } \\
\text { English appropriately in } \\
\text { different social situations }\end{array}$ & & & & & \\
\hline $\begin{array}{l}\text { 5. TEFL should solely be } \\
\text { focused on teaching } \\
\text { English skills }\end{array}$ & & & & & \\
\hline $\begin{array}{l}\text { 6. TEFL curriculum should } \\
\text { include aspects from } \\
\text { English history and } \\
\text { development }\end{array}$ & & & & & \\
\hline $\begin{array}{l}\text { 7. TEFL curriculum should } \\
\text { target theories of teaching } \\
\text { and learning English }\end{array}$ & & & & & \\
\hline $\begin{array}{l}\text { 8. TEFL curriculum should } \\
\text { identify problems that } \\
\text { Arab learners face and } \\
\text { provide solutions }\end{array}$ & & & & & \\
\hline $\begin{array}{l}\text { 9. TEFL should include } \\
\text { a sociolinguistic } \\
\text { component }\end{array}$ & & & & & \\
\hline $\begin{array}{l}\text { 10. TEFL curriculum needs to } \\
\text { be relevant to learners' } \\
\text { context }\end{array}$ & & & & & \\
\hline $\begin{array}{l}\text { 11. TEFL curriculum needs } \\
\text { to include aspects from } \\
\text { learners' culture }\end{array}$ & & & & & \\
\hline
\end{tabular}




\begin{tabular}{|l|l|l|l|l|l|}
\hline Item & $\begin{array}{l}\text { Strongly } \\
\text { agree }\end{array}$ & Agree & Uncertain & Disagree & $\begin{array}{l}\text { Strongly } \\
\text { Disagree }\end{array}$ \\
\hline $\begin{array}{l}\text { 12. TEFL curriculum needs } \\
\text { to focus on British or } \\
\text { American context }\end{array}$ & & & & & \\
\hline $\begin{array}{l}\text { 13. TEFL curriculum should } \\
\text { focus on aspects from } \\
\text { target culture }\end{array}$ & & & & & \\
\hline $\begin{array}{l}\text { 14. TEFL curriculum needs } \\
\text { to be similar to other } \\
\text { curricula offered in the } \\
\text { native inner circle }\end{array}$ & & & & & \\
\hline $\begin{array}{l}\text { 15. TEFL curriculum needs } \\
\text { to be similar to other } \\
\text { curricula offered by other } \\
\text { local universities }\end{array}$ & & & & & \\
\hline
\end{tabular}

Appendix Two: Questionnaire for MA graduates in TEFL

\begin{tabular}{|c|c|c|c|c|c|}
\hline Item & $\begin{array}{l}\text { Strongly } \\
\text { agree }\end{array}$ & Agree & Uncertain & Disagree & $\begin{array}{l}\text { Strongly } \\
\text { Disagree }\end{array}$ \\
\hline $\begin{array}{l}\text { 1. I studied TEFL to get } \\
\text { better job offers }\end{array}$ & & & & & \\
\hline $\begin{array}{l}\text { 2. TEFL provides adequate } \\
\text { subject knowledge to } \\
\text { teaching English in a } \\
\text { foreign language context }\end{array}$ & & & & & \\
\hline $\begin{array}{l}\text { 3. TEFL provides adequate } \\
\text { pedagogic knowledge } \\
\text { to teaching English in a } \\
\text { foreign language context }\end{array}$ & & & & & \\
\hline $\begin{array}{l}\text { 4. TEFL has many } \\
\text { Anglophone cultural item }\end{array}$ & & & & & \\
\hline $\begin{array}{l}\text { 5. TEFL has unnecessary } \\
\text { Anglophone cultural } \\
\text { items }\end{array}$ & & & & & \\
\hline $\begin{array}{l}\text { 6. TEFL lacks reference to } \\
\text { local culture }\end{array}$ & & & & & \\
\hline
\end{tabular}




\begin{tabular}{|l|l|l|l|l|l|}
\hline Item & $\begin{array}{l}\text { Strongly } \\
\text { agree }\end{array}$ & Agree & Uncertain & Disagree & $\begin{array}{l}\text { Strongly } \\
\text { Disagree }\end{array}$ \\
\hline $\begin{array}{l}\text { 7. TEFL has few references } \\
\text { to local culture }\end{array}$ & & & & & \\
\hline $\begin{array}{l}\text { 8. TEFL should include more } \\
\text { reference to local cultures }\end{array}$ & & & & & \\
\hline $\begin{array}{l}\text { 9. TEFL includes } \\
\text { sociolinguistic } \\
\text { components that } \\
\text { help learners function } \\
\text { effectively beyond } \\
\text { academic contexts }\end{array}$ & & & & \\
\hline $\begin{array}{l}\text { 10. TEFL programme } \\
\text { identified needs of non- } \\
\text { native learners }\end{array}$ & & & & \\
\hline $\begin{array}{l}\text { 11. TEFL curriculum } \\
\text { identified problems that } \\
\text { Arab learners face and } \\
\text { provided solutions }\end{array}$ & & & & \\
\hline $\begin{array}{l}\text { 12. TEFL curriculum should } \\
\text { be focused on learners' } \\
\text { needs in the local context }\end{array}$ & & & & \\
\hline $\begin{array}{l}\text { 13. TEFL curriculum } \\
\text { should have the same } \\
\text { components offered by } \\
\text { universities of the native } \\
\text { inner circle (USA/Britain) }\end{array}$ & & & & & \\
\hline $\begin{array}{l}\text { 14. It is important to include } \\
\text { a thesis component in MA } \\
\text { in TEFL programme }\end{array}$ & & & & \\
\hline $\begin{array}{l}\text { 15. It is important to include } \\
\text { a working portfolio } \\
\text { instead of a thesis in MA } \\
\text { in TEFL programme }\end{array}$ & & & & \\
\hline
\end{tabular}

(Original scientific paper received 19.02.2016; revised 10.06.2016; accepted 11.07.2016) 